\title{
Nitric Oxide Synthase Inhibitor
}

National Cancer Institute

\section{Source}

National Cancer Institute. Nitric Oxide Synthase Inhibitor. NCI Thesaurus. Code C29574.

Any substance that inhibits nitric oxide synthase, an enzyme that catalyzes the production of nitric oxide from L-arginine. Nitric oxide is an important intercellular signaling molecule and inhibition of nitric oxide synthase effects many wide-ranging body processes and systems. 